\section{From the Editor:}

\section{Prof. Das Steÿn 2020}

My father's (1902-1978) first vehicle was an ox waggon. He passed away nearly a decade after the first man landed on the moon in 1969. In his life,${ }^{1}$ considerable changes occurred in the field of technology and in social conditions. The rise in the Free State from poverty after the ravage of the Second Anglo-Boer War (1899-1902), the First World War (1914-1919), the Great Influenza (1918), the Great Depression (1929-1933) and the Second World War (1939-1945) divided the periods prior to or after this chain of events. In fact, each of these events also influenced the world of planning.

What changes will the Corona virus bring about in our society? Nobody knows. Changes can be expected in economies and human behaviour. Consider Castells' (1992) famous article after the fall of Communism in Russia: "The world has changed, can planning change?"

The above changes have, to a large extent, turned the world towards socialism, because modern man wanted to eradicate the risk of difficult times in countries where prosperity allowed it. Planning was also swept away by the redistribution of wealth and the notion of 'who gets what'. However, is planning a power game or was the profession driven in a corner? Some planners in the private sector know that other criteria may also apply, namely that the payability of a project is also important; thus, a capitalistic view of planning.

Somewhere between these two value systems, one will have to seek what planning really ought to be.

Christian philosophy (Philosophy of the Cosmononic Idea ${ }^{2}$ ) attempts to determine the unique nature of every type of community or social relationship. The profession of town planning needs to reconsider

1 As a fifty-year old man from the farm, he had to go to town working as a labourer cleaning workshop floors at the South African Railways, so that he could pay the hostel fees of his oldest son, who had to go to high school.

2 For more information on the Philosophy of the Law-Idea, see Kalsbeek (1975) and Dooyeweerd (1953)

Van die redakteur:

\section{Prof. Das Steÿn 2020}

My vader (1902-1978) se eerste voertuig was 'n ossewa. Hy is oorlede byna 'n dekade na die eerste man in 1969 op die maan geland het. In sy lewe ${ }^{1}$ het groot veranderinge op tegnologiese gebied, maar ook in maatskaplike toestande, plaasgevind. Die opstaan in die Vrystaat uit armoede na die verwoesting van die Tweede Vryheidsoorlog (18991902), die Eerste Wêreld Oorlog (1914-1919), die Groot Griep (1918), die Groot Depressie (1929-1933) en die Tweede Wêreld Oorlog (1939-1945). Alles gebeurtenisse wat tydperke tussen gebeure voor dit of daarna verdeel het.

Wat wel waar is, is dat elk van bogenoemde gebeurtenisse ook die wêreld van beplanning beïnvloed het.

Watter verandering gaan die huidige Koronavirus oor ons samelewing bring? Niemand weet presies nie, maar daar kan verwag word dat ekonomieë en menslike gedrag hierna verander gaan wees. Hier kan gedink word aan Castells (1992) se bekende artikel na die val van kommunisme in Rusland: "The world has changed, can planning change?"

Bogenoemde reeks veranderinge het meestal die wêreld al meer sosialisties gemaak, want die moderne mensdom wou die risiko van swaarkry uitskakel in die lande waar welvaart dit toegelaat het. Hierdeur is beplanning ook meegevoer in die vaart na herverdeling van rykdom en die 'wie kry wat gedagte'. Maar is beplanning net 'n spel om mag of het die professie homself in 'n hoek vasgeverf? Sommige beplanners wat in die privaat sektor werk, weet dat ander maatstawwe ook mag geld, soos dat die betaalbaarheid van 'n projek ook van belang is, dus 'n kapitalistiese benadering tot beplanning. lewers tussen hierdie twee waardesisteme sal gesoek moet word na waaroor beplanning regtig behoort te gaan.

\footnotetext{
1 Hy moes as vyftigjarige man van die plaas af, in die stad gaan werk om as arbeider werkwinkelvloere skoon te vee by die Suid-Afrikaanse Spoorweë, sodat hy my oudste broer wat hoërskool toe moes gaan se koshuisgelde kon betaal.
}

Ho tsoa ho mohlophisi:

\section{Prof. Das Steÿn 2020}

Koloi ea pele ea ntate oa ka (1902 - 1978) e ne e le sekosekara likhomo. O hlokahetse lilemo tse ka bang leshome ka mor'a hore monna oa pele a fihle khoeling ka 1969. Bophelong ba hae ${ }^{1}$, ho ile ha etsahala liphetoho tse kholo tsa botsebi, mahlale le 'moho le boiphihlelo maemong a bophelo. Tsena li kenyelelotse ho phahama ha Forei Stata ho tsoa bofutsaneng kamora tšenyo ea Ntoa ea Bobeli ea Boipuso (1899-1902), Ntoa ea Pele ea Lefatše (1914-1919), Seoa sa Sefuba (1918), Seoa sa Moruo (1929-1933) le Ntoa ea Bobeli ea Lefatše (1939-1945). Eleng liketsahalo tsohle tse arohanyang linako pakeng tsa liketsahalo, pele kapa kamora tsona. 'Nete ke hore' e 'ngoe le e 'noe ea liketsahalo tsena e amme lefatše la ho rala.

Koronavirus ea hona joale e tla tlisa phetoho efe sechabeng sa rona? Ha ho na motho ea tsebang hantle, empa moruo le boitšoaro ba batho li ka lebelloa ho fetoha kamora sena. Mona u ka nahana ka sengoloa se tummeng sa Castell (1992) kamora ho oa ha bokomonisi Russia: "Lefatše le fetohile, na ho rala ho ka fetoha?"

Liphetoho tse boletsoeng kaholimo li entse hore lefatše le be le setsoalle haholo hobane ka botho ba sejoalejoale, linaha tse ruileng li lakatsa ho felisa tshoso e tlisoang ke tlokotsi tsena. Sena se kenyeletsa le ho rala leeto la tsamaiso ea moruo le ea "monahano oa hore na mang o fumana eng". Empa na ho rala ke papali feela ea matla kapa ke mosebetsi o ipaketseng sekhutlong? Basebeletsi ba bang ba thero ea litoropo makaleng a kantle ho mmuso ba ka tseba tekanyo tse lokelang ho eloa hloko, joaloka theko e tlase ea merero ea ntshetsopele, eleng mokhoa oa bohoebi oa ho rala. Lipakeng tsa litsamaiso tsena tse peli, motho o lokela ho lekolisisa

\footnotetext{
1 Joaloka monna ea lilemo tse mashome a mahlano ea tsoang polasing, o ile a tlameha ho ea toropong mme a sebetsa teng e le mohloekisi femeng ea Seporo le Literene ea Afrika Boroa, e le hore a tsebe ho lefa litefiso tsa hostele tsa abuti oa ka e moholo, ea neng a tlameha ho ea sekolong se phahameng ka nako e'o.
} 
the nature and character of the profession.

\section{According to Van Riessen}

(1973: 337-356), the test for community development is the establishment of stable relationships ${ }^{3}$ within a community, between active, free and responsible people. In philosophy, every social relationship has a guiding or leading function and a qualifying or destination function. The guiding function is usually of a historical nature and the destination function is linked to the nature of the social relationship. It is important that each social relationship has the authority to reign over its own territory. The authority is thus limited by its unique nature. Independent relationships guarantee freedom, also known as 'sphere sovereignty'. Kuyper stated the following: "Sonder soewereiniteit in eie kring is die staatsmag onbepaald gebiedend; beskik dit oor persone, oor hul lewens, hul regte, oor hul gewete en selfs oor hul geloof" (Translation: "Without sphere sovereignty, state power is indefinitely imperative; it has the power over persons, their lives, their rights, their conscience and even their faith"). (Kalsbeek, 1970: 89). The authority of the church, the school, a business and any other social relationship is equally limited.

A business' origin function is the historical demand for a specific service or product and the destination function is profit. With town planning, the origin function was the historical social and spatial chaos that arises in a complex society and the destination function is to order space so that there is a place in the sun for everyone (Van den Berg, 1981: 27, 41). The destination function not only determines the typical nature of the social relationship, but also directs all its functions towards an individual objective, so that the functions obtain an inner structural order (Van Riessen,1980: 204-215). It is interesting to note that Van den Berg

3 Kalsbeek (1970: 201; 1980: 197) distinguishes between organised communities (for example, state, church, association, industry, and so on) that are also called relationships, and natural communities (for example, marriage and family). Planning is also an organised social relationship, because it is organised as a profession.
In die Christelike filosofie (Wysbegeerte van die Westsidee ${ }^{2}$ ) word gepoog om die eie aard van elke tipe organisasie of samelewingsverband te bepaal. Dit is nodig vir die stadsbeplanningsprofessie om weer te herbesin oor wat die aard en wese van die professie is.

\section{Volgens Van Riessen}

(1973: 337-356) is die toets van gemeenskapsvorming die vestiging van duursame maatskapsverbande ${ }^{3}$ in 'n gemeenskap, tussen aktiewe, vrye en verantwoordelike mense. In die filosofie leer mens dat daar vir elke samelewingsverband 'n ontstaansfunksie en 'n bestemmingsfunksie is.

Die ontstaansfunksie is gewoonlik histories van aard en die bestemmingsfunksie is gekoppel aan die aard van die samelewingsvorm. Wat wel van belang is, is dat elke samelewewingsverband die gesag het om te heers op eie terrein en die gesag word dus begrens deur die eie aard. Vryheid word dus gewaarborg deur die selfstandigheid van die verbande, ook bekend as soewereiniteit in eie kring. Kuyper het dit soos volg gestel: "Sonder soewereiniteit in eie kring is die staatsmag onbepaald gebiedend; beskik dit oor persone, oor hul lewens, hul regte, oor hul gewete en selfs oor hul geloof' (Kalsbeek, 1970: 89). Net so is die mag van die kerk, die skool, die bedryf en enige ander samelewingsverband beperk.

So sal 'n besigheid se ontstaansfunksie wees die historiese vraag na 'n sekere diens of produk en die bestemmingsfunksie is wins. By die stadsbeplanningsprofessie was die ontstaansfunksie die historiese maatskaplike en ruimtelike chaos wat in 'n komplekse samelewing ontstaan en die bestemmingsfunksie is om die ruimte te orden sodat

2 Vir meer inligting oor die Wysbegeerte van die Wetsidee, sien Kalsbeek (1975) en Dooyeweerd (1953).

3 Kalsbeek (1970: 201; 1980: 197) onderskei tussen georganiseerde gemeenskappe soos kerk, staat, vereniging, besigheid, ensovoorts, wat ook verbande genoem word, en natuurlike gemeenskappe soos huwelik, gesin en familie. Beplanning is ook ' $n$ georganiseerde gemeenskapsverband, want dit is as ' $n$ professie georganiseer. hantle hore na boleng thero ea litoropo ke bofeng na.

Ho e aka maikutlo a Bokreste, (Maikutlo a ba naha tsa Bophirima²), ho etsoa boiteko ba ho khetholla mofuta boleng ba sebopeho sa mofuta o mong le o mong oa mokhatlo kapa sechaba. Hoa hlokahala hore mosebetsi oa ho rala litoropo o nahanisise hape ka semelo le sebopeho sa mosebetsi ona.

Ho ea ka Van Riessen

(1973: 337-356), thahlobo ea kaho ea sechaba ke ho theha likamano tse tsitsitseng sechabeng ${ }^{3}$, lipakeng tsa batho ba mafolofolo, ba lokolohileng le ba nang le boikarabelo. Ka thuto ea maikutlo, motho o ithuta hore ho na le lebaka la tshimoloho le lebaka la pheletso sechabeng se seng le se seng. Tshebetso ea tshimoloho hangata e amana le nalane ea sechaba, ha tshebetso ea pheletso eona e ikamahanya le sebopeho sa sechaba. Leha ho le joalo, ho bohlokoa ke hore mokhatlo o mong le o mong oa sechaba o na le matla a ho busa libakeng tsa ona mme bolaoli bo latela tholeho ea bona. Tokoloho ka hona e netefatsoa ke litlamo tsa boipuso, hape bo tsejoang e le bobusi kahare ho selikalikoe sa motho. Kuyper o e beha ka tsela e latelang: "Ntle le borena ka har'a selikalikoe sa puso, matla a mmuso a bohlokoa ka nako e sa lekanyetsoang; mme a rua batho, bophelo ba bona, litokelo tsa bona, letsoalo la bona esita le tumelo ea bona" (Kalsbeek, 1970: 89). Ka mokhoa o ts'oanang, matla a kereke, sekolo, bohoebi le maemo a mang a sechaba a lokela ho lekantshoa.

Kahoo, ts'ebetso ea khoebo ea mantlha e tla ba tlhoko ea nalane ea ts'ebeletso kapa sehlahisoa se itseng, mme qetello e shebiloeng ke phaello. Mosebetsing oa meralo ea toropo, ts'ebetso ea mantlha e ne e le merusu e teng ka maemo a

2 Bakeng sa thaiso-leseling e batsi ka Philosophy ea Cosmononic Idea (Wysbegeerte van die Wetsidee) bala Kalsbeek (1975) le Dooyeweerd (1953).

3 Kalsbeek (1970: 201; 1980: 197) khetholla lipakeng tsa mekhatlo e hlophisitsoeng joalo ka kereke, naha, mekhatlo, khoebo le tse ling hape tse bitsoang maqhama, le likopano tsa tholeho tse kang lenyalo le lelapa. Planning e boetse ke mokhatlo o hlophisitsoeng oa sechaba, hobane o hlophisitsoe e le mosebetsi oa mahlale. 
(1981: 27) distinguishes between planners who are concerned with the science of planning (a planologist "planoloog" in Dutch) and a planner who is concerned with spatial order (a "planner" in Dutch). The one is guided more by science and the other is concerned with the regulation process of space or the filling of space within a specific policy context. Different planners can thus have different functions.

The success of their planning must be tested on the degree in which they succeed in creating or controlling the space in which society can live, work and relax in harmony. According to Nijkamp (1980: 14-18), space (environment) must be created, in order to produce contingencies, set norms, and enrich the soul. Steyn (2015: 122-123) requests that "beplanning daarop gerig moet wees om vir mens en samelewing die voorwaardes te skep om:

- tot groter verantwoordelikheid geroep te voel en gelei te word;

- tot groter vryheid om na eie aard te ontwikkel en moontlikhede te soek, en'

$n$ klimaat te laat ontstaan waarin die mens deur kreatiwiteit 'n ryke verskeidenheid van ruimtelike gebruike, wat in harmonie verkeer, kan ontwikkel."

(Translation: planning should be aimed at creating the conditions for man and society to:

- Feel called and be led to greater responsibility;

- Greater freedom to develop as a unique being and to look for possibilities, and

- Allow a climate to develop in which man can develop, through creativity, a rich variety of spatial uses that are in harmony.)

Planning should not only be restricting, but also realise that man cannot control everything.

"Die toekoms is dus meer kompleks as wat die mens (ook die beplanner) dink. Die veronderstelling dat beplanners weet wat die volgende generasies gaan benodig en dat hul dit nou reeds kan voorsien, is ' $n$ illusie. Die toekoms is onvoorspelbaar en is geen liniêre projeksie van die huidige situasie nie. Die toekoms behels meer daar vir elkeen 'n plekkie onder die son is (Van den Berg, 1981: 27, 41). Die bestemmingsfunksie bepaal nie net die tipiese geaardheid van die samelewingsverband nie, maar rig ook al sy funksies op 'n individuele doel, sodat die funksies 'n innerlike strukturele samehang kry (Van Riessen,1980: 204-215). Interresant is dat Van den Berg (1981: 27) onderskei tussen beplanners wat hul besig hou met die wetenskap van beplanning (so 'n person staan in Nederlands bekend as 'n planoloog) en 'n beplanner wat hom met ruimtelike ordening besig hou, is 'n 'planner' (Nederlands). Die een word meer deur die wetenskap gelei en die ander hou hulself besig met die reguleringsproses van die ruimte of die vulling van ruimte binne 'n bepaalde beleidskonteks. Dus kan verskillende beplanners verskillende hoede opsit.

Die sukses van hul beplanning moet getoets word aan die mate waarin geslaag word om ruimtes te skep of te beheer waarin die samelewing in harmonie kan woon, werk en ontspan. Maar in wese moet ruimte (omgewing), volgens Nijkamp (1980: 14-18), geskep word wat voorwaardeskeppend, normstellend en geesverrykend moet wees. Steyn (2015: 122-123) stel dit "dat beplanning daarop gerig moet wees om vir mens en samelewing die voorwaardes te skep om:

- tot groter verantwoordelikheid geroep te voel en gelei te word;

- tot groter vryheid om na eie aard te ontwikkel en moontlikhede te soek, en

- 'n klimaat te laat ontstaan waarin die mens deur kreatiwiteit 'n ryke verskeidenheid van ruimtelike gebruike, wat in harmonie verkeer, kan ontwikkel."

Beplanning moet dus nie net beperkend wees nie, maar ook besef dat die mens nie alles kan beheer nie.

"Die toekoms is dus meer kompleks as wat die mens (ook die beplanner) dink. Die veronderstelling dat beplanners weet wat die volgende generasies gaan benodig en dat hul dit nou reeds kan voorsien, is 'n illusie. Die toekoms is onvoorspelbaar en is geen liniêre bophelo le tikolohong, e etsahalang sechabeng se rarahaneng, mme ts'ebetso ea pheletso ke ho hlophisa sebaka e le hore ho be le sebaka sa tulo molemong oa motho e mong le e mong ka tlasa letsatsi (Van den Berg, 1981: 27 \& 41). Ts'ebetso ea pheletso ha e hlalose feela sebopeho se tloaelehileng sa khokahano ea sechaba, empa e boetse e lebisa lits'ebetso tsohle tsa eona ka sepheo se le seng, e le hore hobe le tumellano likarolong tsohle tsa sechaba (Van Riessen, 1980: 204215). Ho khahlisang ke hore Van den Berg (1981: 27) o etsa thlalohanyo lipakeng tsa ba keneng molemong oa maano a ho rala, motho ea joalo o tsejoa e le raliphetoho ka puo ea SeDutch, le ea sebetsanang le meralo oa libaka, eleng 'morali' (ho e aka eona puo ea Dutch).

E ngoe e tataisoa haholo ke mahlale 'me e' ngoe e tšoenyehile ka ts'ebetso ea taolo ea libaka kapa ho tlatswa ha sebaka kahare ho melaoana e itseng. Kahona, basebeletsi ba ralang litoropo ba fapaneng ba ka roala likatiba tse fapaneng.

Katleho ea merero ea bona e tlameha ho lekoa ho fihlela ba khona ho theha kapa ho laola libaka tseo sechaba se ka lulang ho tsona, ho sebetsa le ho phomola ka kutloano. Empa haele hantle, ho latela Nijkamp (1980: 14-18), sebaka (tikoloho) se tlameha ho theoa e le ho bopa maemo, ho susumetsa litloaelo le ho khothatsa moea. Steyn (2015: 122-123) o re ho rala ho lokela ho ikemisetsa ho theha maemo a motho le sechaba ho:

- Ikutloa ba bitsitsoe 'me ba fuoe boikarabello bo boholo,

- Tokoloho e kholo ea ho holisa sebopeho se ikhethang sa motho ka mong le ho batla menyetla, mme ba

- Lumella boemo ba kholo moo motho a ka ntlafatsang teng, ka popo, ka mefuta e mengata e fapaneng mme e lumellanang ea tšebeliso ea sebaka.

Thero ea litoropo ha ea tlameha ho ba thata feela, empa hape e lokela ho hlokomela hore motho a ke ke a laola ntho e ngoe le e ngoe.

"Kahoo bokamoso bo rarahane ho feta kamoo batho (mmoho le ba ralang litoropo) ba nahanang. Taba 
as fisiese beplanningsprojeksies. Dit moet die waardes en drome van mense asook teoretiese benaderings inkorporeer in 'n tyd waarin die beplanningsteorie nie weet watter kant toe dinge moet gaan nie. Miskien sal dit help as beplanners nederig genoeg is om te aanvaar dat

- hul beste beplanningsteorieë te gebrekkig is om die werklikheid van die toekoms vas te vang;

- hul beste toekomsprojeksies die kol gaan mis, en

- hul beste planne binne 'n paar jaar nie meer werkbaar gaan wees nie en vervang sal moet word deur ander nuwe toekomsplanne. Laat dus grond (ruimte) oop vir volgende geslagte om oor te besluit en moenie alle besluite nou wil neem nie" (Steyn, 2001: 50).

(Translation: The future is thus more complex than one (also the planner) thinks. It is a misconception to assume that planners know the next generation's needs and that they can already provide these now. The future is unpredictable and is not a linear projection of the present situation. The future includes more than physical planning projections. It must incorporate people's values and dreams as well as theoretical approaches in a time when present planning theories cannot give the answers. It may be helpful if planners are sufficiently humble to accept that

- their best planning theories are too weak to capture the reality of the future;

- their best future projections will miss the point, and

- their best plans will no longer be feasible within a few years' time and will have to be replaced with other new future plans. Thus, leave room for the next generations to decide. Do not make all the decisions now. (Steyn, 2001: 50).

Castells, M. 1992. The world has changed: Can planning change? Landscape and Urban Planning, 22, pp. 73-78.

Dooyeweerd, H. 1953. A new critique of theoretical thought. Vols I, II \& III. Amsterdam: Uitgeverij H.J. Pretorius. projeksie van die huidige situasie nie. Die toekoms behels meer as fisiese beplanningsprojeksies. Dit moet die waardes en drome van mense asook teoretiese benaderings inkorporeer in 'n tyd waarin die beplanningsteorie nie weet watter kant toe dinge moet gaan nie. Miskien sal dit help as beplanners nederig genoeg is om te aanvaar dat

- hul beste beplanningsteorieë te gebrekkig is om die werklikheid van die toekoms vas te vang;

- hul beste toekomsprojeksies die kol gaan mis, en

- hul beste planne binne 'n paar jaar nie meer werkbaar gaan wees nie en vervang sal moet word deur ander nuwe toekomsplanne. Laat dus grond (ruimte) oop vir volgende geslagte om oor te besluit en moenie alle besluite nou wil neem nie" (Steyn, 2001: 50).

Castells, M. 1992. The world has changed: Can planning change? Landscape and Urban Planning, 22, pp. 73-78.

Dooyeweerd, H. 1953. A new critique of theoretical thought. Vols I, II \& III. Amsterdam: Uitgeverij H.J. Pretorius.

Kalsbeek, L. 1970. De wijsbegeerte der wetsidee. Amsterdam: Buijten \& Schipperhein.

Kalsbeek, L. 1975. Contours of a Christian philosophy: An introduction to Herman Dooyeweerd's thought. Amsterdam: Buijten \& Schipperhein.

Nijkamp, P. 1980. Waarden en waarheid in de ruimtelijke wetenskap. Radix, 6(1), pp. 2-19.

Steyn, J.J. 2001. 'n Nuwe sonering vir stads- en streekbeplanning, naamlik 'n "oop toekoms". Stads- en Streekbeplanning, vol. 44, pp. 46-51.

Steyn, J.J. 2015. Reforming normative planning: Essays on a Christian approach to planning / Hervorming vir normatiewe beplanning: Opstelle oor 'n Christelike benadering tot beplanning. Orania: Prisca Uitgewers.

Van den Berg, G.J. 1981. Inleiding tot de planologie: Voor ieder 'n plaats in de zon? Brussel: Samson Uitgeverij. ea hore ba ralang litoropo ba tseba seo meloko e tlang e tla se hloka le seo ba ka fanang ka sona ke ho ithetsa. Bokamoso ha bo hlalosehe 'me ha ho na tsebo ea hore na maemo a teng hajoale a tla nka nako e telele hakae. Bokamoso ha bo felle feela ka ho rala lefatshe ka sebobeho sa lona sa mobu. E tlameha ho kenyelletsa litekanyetso le litoro tsa batho hammoho le mekhoa ea ho ithuta nakong eo ho rala mohopolo o sa tsebeng hore na lintho li lokela ho tsamaea ka tsela efe. Mohlomong ho tla thusa haeba ba ralang ba ikokobelitse ho lekaneng ho amohela hore:

- hore mehopolo ea bona ea meralo le ha e le metle, hae ea lekana ho hlakisa le ho lekanya bonnete ba bokamoso;

- hore litakatso tsa bona tsa bokamoso tse ntle li tla fosahala; le hore

- nakong ea lilemo tse seng kae meralo ea bona e metle ha ena ho hlola e sebetsa kahona e tla hloka ho nkeloa sebaka ke merero e meng e mecha ea bokamoso. Kahoo tlohelang lefatshe (sebaka) le bulehetse meloko e tlang ho etsa qeto mme le se batle ho etsa liqeto tsohle hona joale" (Steyn, 2001: 50).

Castells, M. 1992. The World has changed: can Planning change? Landscape and Urban Planning. Vol 22, 1992:73-78

Kalsbeek, L. 1970. De Wijsbegeerte der Wetsidee. Buijten \& Schipperhein, Amsterdam.

Kalsbeek, L. 1975. Contours of a Christian Philosophy: An Introduction to Herman Dooyeweerd's Thought. Buijten \& Schipperhein, Amsterdam.

Nijkamp, P. Waarden en Waarheid in de Ruimtelijke Wetenskap. Radix, 6 (1): 2-19.

Steyn, J.J. 2001. 'n Nuwe sonering vir stads- en streekbeplanning, naamlik 'n "oop toekoms". Stads- en Streekbeplanning, nr 44 : 46-51. 
Kalsbeek, L. 1970. De wijsbegeerte der wetsidee. Amsterdam: Buijten \& Schipperhein.

Kalsbeek, L. 1975. Contours of a Christian philosophy: An introduction to Herman Dooyeweerd's thought. Amsterdam: Buijten \& Schipperhein.

Nijkamp, P. 1980. Waarden en waarheid in de ruimtelijke wetenschap. Radix, 6(1), pp. 2-19.

Steyn, J.J. 2001. 'n Nuwe sonering vir stads- en streekbeplanning, naamlik 'n "oop toekoms". Stads- en Streekbeplanning, vol. 44, pp. 46-51.

Steyn, J.J. 2015. Reforming normative planning: Essays on a Christian approach to planning / Hervorming vir normatiewe beplanning: Opstelle oor 'n Christelike benadering tot beplanning. Orania: Prisca Uitgewers.

Van den Berg, G.J. 1981. Inleiding tot de planologie: Voor ieder 'n plaats in de zon? Brussel: Samson Uitgeverij.
Steyn, J.J. 2015. Reforming Normative Planning: Essays on a Christian approach to planning / Hervorming vir Normatiewe Beplanning: Opstelle oor 'n Christelike benadering tot beplanning. Prisca Uitgewers, Orania.

Van den Berg, G.J. 1981. Inleiding tot de Planologie: voor ieder 'n plaats in de zon? Brussel, Samson Uitgeverij. 